\title{
How Common is the Common Law? Some Differences and Similarities in British and American Superior Court Decisions
}

\author{
Marion Charret Del-Bove \\ Laurence Francoz-Terminal \\ Université Jean Moulin Lyon 3 \\ laurence.francoz-terminal@univ-lyon3.fr, marion.del-bove@univ-lyon3.fr
}

\begin{abstract}
American law and English law belong to the same legal tradition, the common law, characterized by a case-law system based on judicial decisions and the rule of precedent. There are indeed common features between the American and the English common law systems. There is a common language with close expressions, but also similar concepts, principles and procedures. But how common are in fact the American and British legal systems? This paper aims at finding some possible answers through a legal and linguistic analysis of some US and UK superior court decisions.
\end{abstract}

Keywords: common law, superior courts, discourse structure, legal reasoning, interpretation techniques

\section{Introduction: the beginnings and evolution of the Plain language movement}

The starting point of this paper is the presumption that, as the United States (US) and the United Kingdom (UK) share a common language (English), their respective legal systems may also share a common law. Obviously, American law and English law belong to the same legal tradition, the common law, characterized by a case-law system based essentially on judicial decisions and the rule of precedent. The common law has 
now become one of the most important legal families in the world ${ }^{1}$ alongside with civil law. But how common are the American and British common law systems? To paraphrase Bernard Shaw's words, aren't the UK and the USA two countries separated by a common legal system? This paper aims at finding some possible answers through a legal and linguistic analysis of some US and UK superior court decisions that constitute an interesting indicator of two existing patterns of the common law.

In order to account for the possible common or different features of American and British common law systems, one needs to refer to the historical roots of the two systems. The common law - so called because it was intended to apply uniformly to courts of various jurisdictions- was born in England during the $12^{\text {th }}$ century through the development of the curia regis (King's court) and royal courts that contributed to the gradual establishment of a state in a feudal society. Circuit judges thus spread local custom across the whole territory, which contributed to the establishment of a common set of legal rules. During the $17^{\text {th }}$ century and the rise of the British Empire, those who had emigrated from England to the thirteen British colonies perpetuated and implemented the laws and rules under which they had lived in their homeland throughout the world.

Nevertheless, the newly independent states of America distanced themselves from their English legal roots because of their situation and living conditions. French legal scholars highlight a "separatist" movement (Levasseur, 2004: 4), or a "distancing phenomenon" (Bullier, 2012: 8) in the USA from British legal traditions. While some commonwealth countries developed their own legal principles consistently with the British common law, ${ }^{2}$ American common law walked an autonomous path, especially since the 1776 Declaration of Independence and the adoption of a single written constitution in 1789. This clearly severed the bonds between the colonies and the British Crown and marked a turning point in the development of American common law, separately and autonomously from English judicial decisions. The latter were no longer used as binding precedents by American courts. Initially the laws of the American colonies were intended not to contradict the laws of the Realm of England, though inevitably "the British common law was eluded when the settlers considered it as inappropriate, inadequate or going against their interests or convictions" (Zoller, 2014: 5), ${ }^{3}$ as confirmed by Blackstone, in his famous Commentaries:

Such colonists carry with them only so much of the English law as is applicable to their own situation and the condition of an infant colony; such, for instance, as the general rules of inheritance, and of protection from personal injuries. The artificial refinements and distinctions incident to the property of a great and commercial people, the laws of police and revenue, (such especially as are enforced by penalties,) the mode of maintenance for the established clergy, the jurisdiction of spiritual courts, and a multitude of other provisions, are neither necessary nor convenient for them, and therefore are not in force (1893: 85-86).

Consequently, even though the USA did adopt common law rules and procedures originating from English common law during the $17^{\text {th }}$ and $18^{\text {th }}$ centuries, American law 
today is clearly distinct from English law. The multiple and profound changes undergone by American common law were mainly conditioned by their new political environment as well as human experience and geographical living conditions. The traditional English opposition between Chancery courts and common law courts, for example, was not transposed to the USA, as Oliver Wendell Holmes argued in Black and White Taxicab \& Transfer Co. v. Brown \& Yellow Taxicab \& Transfer Co. (276 U.S. 518):

The common law so far as it is enforced in a State, whether called common law or not, is not the common law generally but the law of that State existing by the authority of that State without regard to what it may have been in England or anywhere else (1928: 533534).

The strength of the common law is often said to lie in its capacity to develop and adapt to the environment in which it is applied. The fact that American and British societies developed autonomously naturally gave birth to acculturated laws that now differ to some extent in the US and the UK, as stated in the British case Sue Axon v. The Secretary of State for Health (The Family Planning Association) [2006] EWHC 37 (Admin) regarding the question of abortion:

[A] second reason why the American cases do not assist in this case is that the social and moral values of American society are very different from those which are prevalent in the United Kingdom. There is sensitivity and a controversy regarding the availability of abortion which does not exist on a comparable scale in this country (Justice Silber, 2006: $\S 37)$.

Acculturation, in this context, refers to the fact that case law follows the needs and expectations of the society where it is applied, which explains that the common law has evolved in the USA and the UK in keeping with acculturation phenomena. As a consequence, even if American law takes its roots in English law, the two countries being culturally different, their respective legal systems logically diverge to some extent. Amongst the main factors which explain why American common law came to differ from its English counterpart, Levasseur highlights the existence of a federal government, a written constitution and a specific procedure of judicial review (69).

In order to underscore the possible similarities and divergences between American and British common law superior court decisions, our paper focuses on three main areas: the differences between the workings of the US and UK Supreme Courts, an analysis of the discourse structure of US and UK superior court decisions and the terminology used by American and British judges and finally, legal reasoning methods applied in both American and British common law. 


\section{Differences between the workings of US and UK Supreme Courts}

A first common feature of the American and British legal systems lies in the fact that both have a supreme court. The US Constitution, also called "the Supreme law of the land", provides that the judicial power is vested in one Supreme Court and other federal courts. ${ }^{4}$ This constitutional court, which sat for the first time in 1790 and is currently composed of nine justices (the Chief Justice of the United States and eight Associate Justices), rules on hundreds of appeal cases every year, from early October until July. The current English judicial system, which was first organized by the 1873 and 1875 Judicature Acts and its following amendments, was profoundly changed in 2005 with the passage of the Constitutional Reform Act which replaced the Appellate Committee of the House of Lords by the UK Supreme Court as the leading judicial authority in charge of scrutinizing the application of the common law within the UK. Currently, twelve UK Supreme Court Justices hear appeals on legal questions of public importance from the beginning of October until the end of July.

At first sight, both supreme courts would seem to share common features: they are situated at the apex of their respective court systems in which a similar notion of hierarchy between inferior courts and superior courts is applied and both US and UK Supreme Court judges decide to grant or deny permission to present the appealed case to the court by selecting the cases they consider worth reviewing in the light of the significant legal issues at stake. ${ }^{5}$ Nevertheless, one important difference lies in the fact that the US Supreme Court exercises a unifying role on federal and constitutional law, whereas in the UK the situation is different inasmuch as Scotland, Wales and Northern Ireland have, to a greater or lesser degree, kept their judicial autonomy, their own court systems and legal principles, as explained on the official website of the UK Supreme Court:

For historical reasons, as a state made up of several separate jurisdictions, the United Kingdom does not have a single unified legal system. Instead, there is one system for England and Wales, another for Scotland, and a third for Northern Ireland. ${ }^{6}$

The UK, then, is a non-unified legal system with three jurisdictions (England and Wales, Northern Ireland, Scotland) leading to the existence of a number of judicial particularities such as, for instance, the High Court of Justiciary ${ }^{7}$ which is Scotland's supreme criminal court. However, the UK Supreme Court retains jurisdiction when an infringement of human rights is alleged under the Human Rights Act 1998 or when a devolution or compatibility issue is raised under the Scotland Act 2012. ${ }^{8}$ Consequently, even if both the American and British legal systems have a supreme court, it is clear that their roles are not entirely similar.

Federalism is the cornerstone of the American political system of government. As such, the US Supreme Court fulfils two main functions; firstly, it interprets federal (and at times state) laws brought before the court within the framework of a particular case in which one or several legal questions are raised. For instance, in Lawrence v. Texas 539 U.S. 558 (2003), the legal question raised was to determine if the criminal convictions 
of John Lawrence and Tyron Garner under the Texas "Homosexual Conduct" law (section 21.06 Homosexual Conduct Texas Penal Code), which criminalized sexual intimacy by same-sex couples but not identical behaviour by different-sex couples violated their Fourteenth Amendment guarantee of equal protection under the law. This example, among many others, goes to illustrate the fact that the vocation of the US Supreme Court is not to unify state laws by imposing a federal common law but rather, to guarantee the respect of the U.S. Constitution on the part of all states. Secondly, the US Supreme Court exercises judicial review -i.e. the authority to invalidate legislative acts if contrary to the constitution-since its judges bear the ultimate responsibility of ensuring that legislative, executive and administrative actions are in keeping with the Constitution. In a pending case, the Court is invited to confirm (or not) the constitutionality of the challenged state or federal law(s). Judicial review, even if not explicitly mentioned in the Constitution, is one of the pillars of American rule of law. In the 1803 landmark case Marbury v. Madison, the US Supreme Court took the initiative of interpreting the Constitution to mean that one of the key constitutional roles of the judicial branch was to check the constitutionality of a federal statute. From then onwards, American common law acquired a specific dimension alien to English common law.

Unlike the US Supreme Court, the UK Supreme Court is not a constitutional court, strictly speaking. Although guaranteeing the application of the common law in the UK, the protection of human rights and the non-infringement of the body of laws of a constitutional nature, ${ }^{9}$ it does not check the constitutionality of laws. ${ }^{10}$ French legal ELP specialist Gibson-Morgan points out the main difference between the US and UK Supreme Courts when she underlines that "The UK Supreme Court was not modelled on the federal Supreme Court" (2014: 94). On the one hand, the UK Supreme Court is bound by parliamentary sovereignty, which prevents it from going against statute law. Additionally, there is no distinction of nature between constitutional principles or texts as the fundamental legal standards, and ordinary legislation passed by the British legislature, both are Acts of Parliament. The role of the UK Supreme Court is then to scrutinize the application of the common law in a non-unified legal system. This role differs from its American counterpart, described as the Keeper of the Constitution that protects individual constitutional rights. On the other hand, considering the different nature of US and UK political systems, the UK Supreme Court is not a federal court even if it guarantees some degree of legal uniformity over the different jurisdictions of the UK.

Finally, there ensues from the differences in function between the US and UK Supreme Courts that distinctions in terminology exist as well. One of the most significant is related to the notion of "judicial review", a term which exists in both the American and British legal systems but refers to two different concepts. In American English, judicial review refers to "the ability of the court to declare a Legislative or Executive act in violation of the Constitution", ${ }^{11}$ as Garner further explains in his Dictionary of Modern Legal Usage: 
The BrE [British English] uses are quite different because G.B. [sic] does not have judicial review in the American sense: courts cannot invalidate primary legislation (though they review the decisions of lower courts). British writers use judicial review to refer to a relatively new procedure in England [...] that enables a litigant to challenge an administrative action by a public body (485).

It is clear, then, that the US Supreme Court stands in sharp contrast to its British counterpart when it exercises judicial review. It has played a vital role in America's social and economic life due to its wide power of interpretation, that is to say "judging primary legislation against fundamental constitutional problems [...] checking whether norms are in agreement with the Constitution" (Gibson-Morgan, 2014: 84). This is particularly true of landmark cases in the field of civil rights such as Brown v. Board of Education of Topeka (1954), often commented on as a clear example of American judicial activism. The case put an end to the discriminatory principle of "separate but equal" established at the end of the $19^{\text {th }}$ century by US Justices themselves and considered as one of the reasons for decades of segregation in certain states.

After this brief overview of some of the differences between American and British common law systems, notably the American principle of the sovereignty of the Constitution being opposed to the British principle of the sovereignty of Parliament, we now focus on questions of language and discourse organisation through an analysis of some US and UK superior court decisions. These texts, listed in the bibliography, have been selected as they highlight the legal mechanisms used to structure court decisions: implementation of the rule of precedent, distinction between ratio decidendi (the principle that the case establishes) and obiter dictum (a remark in a judgment that is "said in passing"), adaptation of case law to societal needs and legal reasoning techniques used by common law judges. Such texts consistently illustrate how structural features have shaped legal discourses and impacted legal language.

\section{Discourse structure of superior court decisions}

In the US, as in the UK, judicial decisions are publicly read during the final hearing and subsequently published in a judgment signed by all the judges. Contrary to French judges who withdraw behind the anonymity of the court, common law judges sign their decisions, aptly called "opinions" in American law. This practice, common to the US and the UK, constitutes the cornerstone of a legal case-law system in which the judges are invited to declare what the law is and justify their statements and interpretations explaining how they reached their conclusion. What does an analysis of the macrostructure of American and British judicial decisions reveal about the divergences and similarities between the US and the UK? To answer the question, we decided to start from what the reader sees at first sight when looking at a court decision in terms of its general layout and formal structure, before moving on to a further analysis of the textual implementation of relevant legal mechanisms. 
To start with, the manner of citing cases is not exactly the same on the two sides of the Atlantic. In the UK, as in the US, a judgment is published by a specialized publisher who may add particular indications in order to make the first approach to the document easier. Firstly, we find the publishing references of the case in the different Law Reports such as in Example 1, a screen shot taken from the British Bailii website. ${ }^{12}$

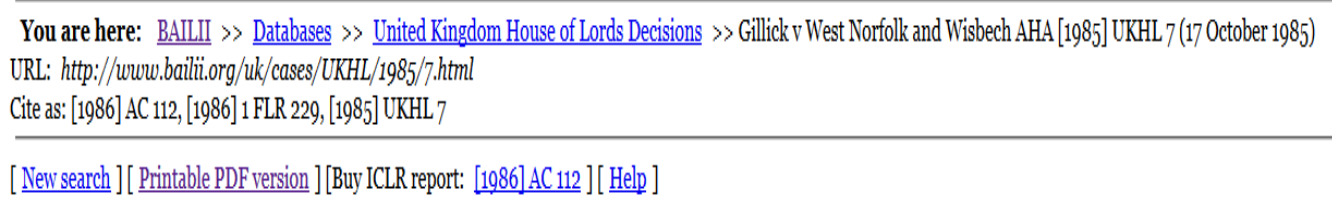

Example 1. Different publishing references of the Gillick case

Since 2001, the system of neutral citation for cases has been implemented in the UK so as to identify a case without referring to any publisher but to the court of law that handed down the decision. The neutral citation refers to the name of the parties (Gillick $v$ West Norfolk and Wisbech AHA), the year of judgment in brackets ([1985]), then the court (UKHL) and finally the case number (7).

To compare if the citation methods are the same, let us take the example of an American case: City of Richmond v. J.A. Croson Co is cited as City of Richmond v. J.A. Croson Co 488 U.S. 469 (1989). As already mentioned, American judicial decisions are first publicly read, then published by specialized publishers and in this citation, "488" refers to the volume in which the decision was published, "U.S." stands for "United States Reports', the name of the publisher, "469" refers to the page from which the quotation is taken and, finally, the year the decision was handed down is indicated. There is no system of neutral citation in American law.

Secondly, the macro-structure of UK and US superior court decisions is characterized by the presence of subparts and references that may not be the same in the two systems. In a UK judgment, the different hearing dates, as well as the date of the hearing of the published decision, are mentioned. These indications are absent from the texts of US Supreme Court decisions when published. Next, in the UK some "catchwords", as referred to by the editing publisher, are inserted which can be useful to identify the legal fields covered by the case at first glance. Such keywords are not included within American judicial decisions. The next subpart, called "headnote" in English law, summarizes the relevant facts of the case and its context. In American common law, when a decision is published, a part is added to the text originally read in court when the decision is announced. This introduction, called "syllabus", consists in a summary of the decision with the key arguments raised in the majority opinion (see Example 2). 


\title{
Syllabus
}

NOTE: Where it is feasible, a syllabus (headnote) will be released, as is being done in connection with this case, at the time the opinion is issued. The syllabus constitutes no part of the opinion of the Court but has been prepared by the Reporter of Decisions for the convenience of the reade

\section{SUPREME COURT OF THE UNITED STATES}

\author{
Syllabus \\ MORSE ET AL. $v$. FREDERICK \\ CERTIORARI TO THE UNITED STATES COURT OF APPEALS FOR \\ THE NINTH CIRCUIT
}

No. 06-278. Argued March 19, 2007-Decided June 25, 2007

At a school-sanctioned and school-supervised event, petitioner Morse, the high school principal, saw students unfurl a banner stating "BONG HiTS 4 JESUS," which she regarded as promoting illegal drug use. Consistent with established school policy prohibiting such messages at school events, Morse directed the students to take down the banner. When one of the students who had brought the banner to the event-respondent Frederick-refused, Morse confiscated the banner and later suspended him. The school superintendent upheld the suspension, explaining, inter alia, that Frederick was disciplined because his banner appeared to advocate illegal drug use in violation of school policy. Petitioner school board also upheld the suspension. Frederick filed suit under 42 U. S. C. $\$ 1983$, alleging that the school board and Morse had violated his First Amendment rights. The District Court granted petitioners summary judgment, ruling that they were entitled to qualified immunity and that they had not infringed Frederick's speech rights. The Ninth Circuit reversed. Accepting that Frederick acted during a school-authorized activity and that the banner expressed a positive sentiment about marijuana use, the court nonetheless found a First Amendment violation because the school punished Frederick without demonstrating that his speech threatened substantial disruption. It also concluded that Morse was not entitled to qualified immunity because Frederick's right to display the banner was so clearly established that a reasonable principal in Morse's position would have understood that her actions were unconstitutional.

Held: Because schools may take steps to safeguard those entrusted to their care from speech that can reasonably be regarded as encouraging illegal drug use, the school officials in this case did not violate the

Example 2: Part of the syllabus in an American case

Deborah Morse, et al., Petitioners v. Joseph Frederick 551 U. S.

Each time a ruling is published, the syllabus is introduced at the top of the first page of the document with the following paragraph:

NOTE: Where it is feasible, a syllabus (headnote) will be released, as being done in connection with the case, at the time the opinion is issued. The syllabus constitutes no part of the opinion of the Court but has been prepared by the Reporter of Decisions for the convenience of the reader. See United States v. Detroit Timber \& Lumber Co, 200 U.S. $321,327$. 
This was clearly indicated in the 1906 Detroit case, when US Justices pointed out that "the headnotes of the opinions of this Court are not the work of the Court, but are simply the work of a Reporter, giving his understanding of the decision ..." (ibid., 327). Consequently, these introductory remarks may simply be interpreted as providing reader guidance as to what was decided and how, but have no legal value per se.

In the judicial decisions of both countries, the headnote (or syllabus) is immediately followed by a short summary of the judgment introduced by the word "Held". This summary focuses on the leading judgment and the points of law scrutinized by the court. Such a presentation is the same in US and UK superior court decisions as illustrated in the extract above taken from Deborah Morse, et al., Petitioners v. Joseph Frederick 551 U. S. (2007). Another difference between American and British common law systems lies in the presence or absence of references to dissenting opinions. In the US, the syllabus does not include any precise references to the existing concurring or dissenting opinions that are actually published in the text of the ruling. On the other hand, in the English part called "headnote", all dissenting positions are highlighted with reference to the name of the dissenting judge so as to make it easier to find the relevant information in the body of the text.

In the UK, depending on the publisher, other decisions have notes which refer to the paragraphs of the Digest of the Legal Encyclopedia (Halsbury's Law and Halsbury's Statutes) to which the legal issues are related, in order to guide the reader with regard to the doctrinal position on this issue. Such is not the practice in American common law. Next, there follows an exhaustive list of all cases the judges refer to in the obiter dictum (see Example 3), which is not a practice used in decisions handed down by the US Supreme Court.

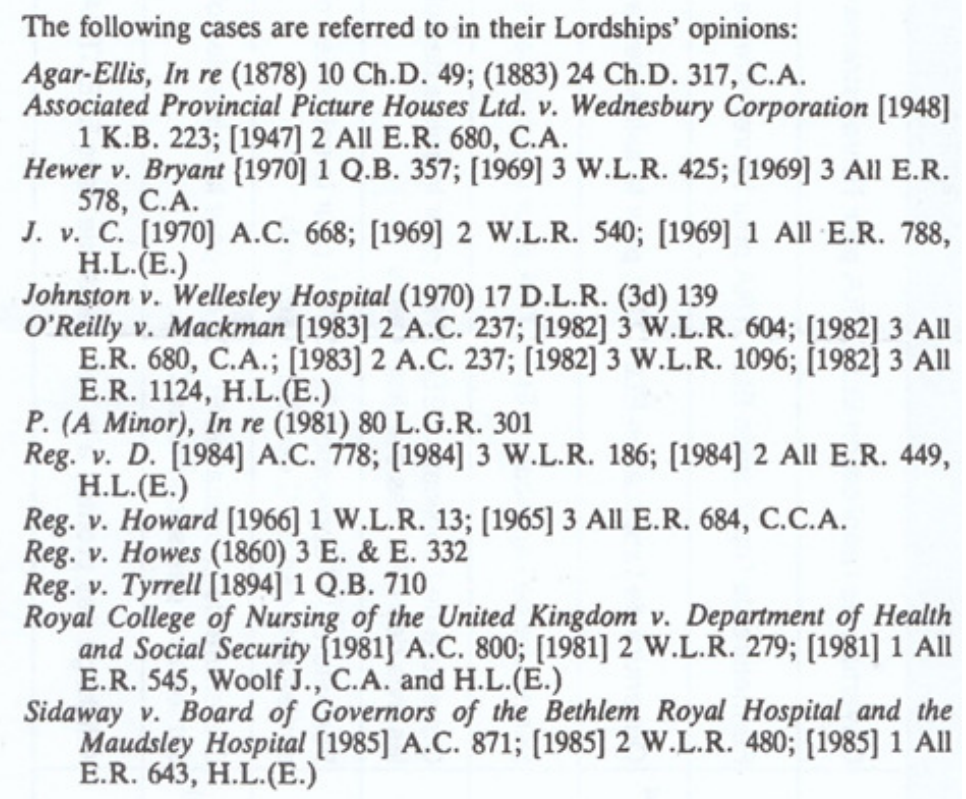

Example 3: List of the cases referred to in the Gillick case, extract taken Gillick $v$ West Norfolk \& Wisbeck Area Health Authority [1986] AC 112, 115 
Finally, there is the judgment ${ }^{13}$ itself. The judgment of each British judge is presented in extenso, one judgment after the other. Each judgment is released in a single block of opinion with an internal structure, usually following the different legal issues that have been assessed, ${ }^{14}$ but without any subparts. The dissenting opinions are not eluded; they are published equally to the leading position, but are identified as dissenting for a clear understanding of the decision, as discussed in more detail below. In some of the British decisions selected here, each opinion concludes with expressions such as "I have had the advantage of reading in draft the speech prepared by my noble and learned friend, [...]. I agree with it and for the reasons he gives I would dismiss this appeal" (Lord Templeman, 1994: 2, Murray v DPP). In American Supreme Court decisions, US justices explicitly express their disagreement in dissenting opinions as, for example Justice Sotomayor in Berghuis v. Thompkins 560 U.S. (2010): "and because the Court's answers to those questions do not result from a faithful application of our prior decisions, I respectfully dissent" (2010: 2, dissenting opinion).

Finally, the structure of a UK superior court decision stands in sharp contrast with the structure of a US Supreme Court decision. Between 1801 and 1835, under Chief Justice Marshall, the English practice of seriatim judicial opinion, i.e. each opinion read individually, was discontinued. Nowadays, the text of an American ruling in a given case is composed of several parts, as illustrated in Glossip v. Gross 576 U.S. (2015):

ALITO, J., delivered the opinion of the Court, in which ROBERTS, C. J., and SCALIA, KENNEDY, and THOMAS, JJ., joined. SCALIA, J., filed a concurring opinion, in which THOMAS, J., joined. THOMAS, J., filed a concurring opinion, in which SCALIA, J., joined. BREYER, J., filed a dissenting opinion, in which GINSBURG, J., joined. SOTOMAYOR, J., filed a dissenting opinion, in which GINSBURG, BREYER, and KAGAN, JJ., joined (2015: 3-4, syllabus).

First, there is the opinion of the Court, also called the majority opinion, i.e. the enforceable part of the decision which has legal effect, delivered here by Justice Alito. It corresponds to the text agreed upon by a majority of the judges and written either by the Chief Justice if s/he is in the majority or another justice chosen by the Chief Justice. If the latter is not in the majority, the majority will decide who drafts the opinion of the Court. There is also the possibility of having concurring opinions (two in the above example). A concurring opinion is drafted by a judge who agrees with the majority decision but may base his or her own decision on complementary or different arguments. Finally, there are dissenting opinions (two in the above example) when judges in the minority want to draft their own text to express their disagreement with, and at times harsh criticism of, the arguments presented in the opinion of the Court. Each justice may conclude his or her text by saying "I concur" or "I dissent". And, as illustrated above, it is even possible to concur with a dissenting opinion. Some US Justices are famous for their dissents as, for example, Justice Harlan in Plessy $v$. Ferguson (1896) or Sonia Sotomayor in more recent cases such as Schuette, Attorney 
General of Michigan v. Coalition to defend Affirmative Action, Integration and Immigration Rights and Fight for Equality by any Means Necessary (BAMN) et al. (2014):

But I part ways with the plurality when it suggests that judicial intervention in this case "impede[s]" rather than "advance[s]" the democratic process and the ultimate hope of equality. Ante, at 16. I firmly believe that our role as judges includes policing the process of self-government and stepping in when necessary to secure the constitutional guarantee of equal protection. Because I would do so here, I respectfully dissent (2014: 6, dissenting).

In the UK, superior court cases are held in consistence with the position of the majority of judges. Generally, the first judgment presented when a decision is published is the most important one with respect to the legal issues at stake and represents the leading opinion. In lower court decisions, where a consensus is reached on the case, only one judgment may be presented in extenso, while the two other judges' opinions are limited to a simple expression, "I agree". Where no consensus is reached, each opinion counts. In order to make these accessible to legal practitioners, all the opinions are published comprehensively, either concurring with or dissenting from the leading one that ruled the case.

These structural differences may originate from the drafting process which varies between the US and the UK. US Justices hear oral arguments from both sides during generally two weeks. They then spend several weeks deliberating, passing a draft of the decision between each other until the writing of a final text. This version has to be approved by a majority of five votes at least. Judges in the minority will proceed similarly. Due to this collective drafting process, the text of an American judicial decision is composed of different parts. On the other hand, the British drafting process seems different even though it evinces the same plurality of judges and judgments. Where American judges' opinions are presented according to their position (in the majority, concurring or dissenting), no such presentation is highlighted in British cases. In spite of divergences in textual organisation between American and British common law systems, US and UK superior court decisions share one common structuring mechanism, the doctrine of stare decisis or the rule of precedent, that similarly shapes judicial discourse.

In the two countries, stare decisis is the linchpin of common law. In order to discover how the mechanism of precedent works, English law students are usually taught how to distinguish the two different parts of the decision: ratio decidendi (i.e. the rule of law that is binding over cases on similar relevant facts) and obiter dictum (i.e. the legal reasoning followed by the judge to argue his/her position, but which has no legally binding framework). Distinguishing between the two is not an easy task considering the number and length of common law judicial decisions since these two parts coexist but are not clearly distinguished. British judges are not expected to construct their legal reasoning on the basis of structured discourse organisation. As a consequence, what belongs to ratio decidendi, and what must be read as obiter dictum 
is left for legal practitioners and academics to discover and is sometimes subject to controversy.

Ratio decidendi is the legal decision strictly speaking. In other words, what will remain as a legal principle and what is intended to become the legal precedent that will bind lower courts in similar subsequent cases. Consequently, ratio decidendi is considered as the most important part of the decision, even when it is expressed in a fewer number of words compared to the length of the obiter dictum. Most of the time, ratio decidendi is formulated unambiguously so as to avoid any diverging interpretation. Following are two examples which serve to illustrate the differences between the two parts of a British judicial decision. The first one is taken from $R v$ Howe \& Bannister [1987] AC 417:

(...) As I can find no fair and certain basis upon which to differentiate between participants to a murder and as I am firmly convinced that the law should not be extended to the killer, $I$ would depart from the decision of this House in Director of Public Prosecutions for Northern Ireland v. Lynch [1975] A.C. 653 and declare the law to be that duress is not available as a defense to a charge of murder, or to attempted murder. I add attempted murder because it is to be remembered that the prosecution have to prove an even more evil intent to convict of attempted murder than in actual murder. Attempted murder requires proof of an intent to kill, whereas in murder it is sufficient to prove an intent to cause really serious injury. It cannot be right to allow the defense to one who may be more intent upon taking a life than the murderer. This leaves, of course, the anomaly that duress is available for the offence of wounding with intent but not to murder if the victim dies subsequently. But this flows from the special regard that the law has for human life, it may not be logical but it is real and has to be accepted." (Lord Griffiths, 1987: 17, our italics to underline the ratio decidendi)

In the judgment of a superior court, where the legal issue at stake is a complex one, several ratio decidendi may be highlighted in the same case, ratio decidendi being the legal principle that emerges from the case and subsequently considered as binding in a factually similar situation. Indeed, as opposed to the mandatory character of statutes, case law is binding only with respect to the particular facts of the case: a precedent is followed only insofar as it relates to similar facts. It does not set an absolute general rule of law taken in its civilian meaning. Rather, it settles a specific legal issue that arose from a particular set of facts and circumstances, as the Earl of Halsbury L.C. stated in Quinn v Leathem [1901] AC 495:

(...) Now, before discussing the case of Allen v. Flood (1) and what was decided therein, there are two observations of a general character which I wish to make, and one is to repeat what I have very often said before, that every judgment must be read as applicable to the particular facts proved, or assumed to be proved, since the generality of the expressions which may be found there are not intended to be expositions of the whole law, but governed and qualified by the particular facts of the case in which such expressions are to be found (para. 1). 
Consequently, as A. L. Goodhart pointed out, ratio decidendi is rooted in the "material facts of the case" 15 and, as such, the context of the case framed in obiter dictum is crucial. ${ }^{16}$ The same principle is found in American common law through the legal reasoning of analogy.

A court opinion using legal analogy will cite precedents deemed favorable and attempt to distinguish precedents deemed unfavorable. The court may attempt to distinguish a previous decision by showing that it rests on a different set of facts than the present case or that the rationale of the previous decision is inapplicable to the present case (Regan, 2015: 366).

Under the principle of analogy, like cases should be treated alike in material respects. So if case $B$ is like case $A$, then case $B$ should be decided the same way as case A. And if case B is not like case A, then case B should not be decided the same way as case A.

In obiter dictum judges explain their reasoning regarding the facts and the legal issues at stake. This part of the judgment can be compared to the reasoning followed by the judge to reach ratio decidendi. Obiter dictum, although not binding, is a very important part of the case in many respects. Indeed, the framework of the case is essential for the legal practitioner who examines the material facts of the case in order to know whether it should be regarded as binding or not. It also helps to identify the context in which the legal principle has been held and shed light on the scope of the decision. ${ }^{17}$ Moreover, it is in obiter dictum that some of the most beautiful pieces of legal reasoning are to be found and where the implementation of the common law mechanism of precedent is seen in action. Indeed, in obiter dictum the judge scrutinizes the previous decisions held on similar legal issues and assesses whether or not they should be regarded as binding upon the present case.

Although the elements contained in obiter dictum are not binding, they can be reused by other judges in their legal reasoning or even in subsequent ratio decidendi. In this respect, it is worth quoting the $R$. $v$ Howe case a second time since it is relevant when analysed in relation to $R v$ Gott as a good illustration of the way obiter dictum can later be re-used as ratio decidendi (see Example 4).

\begin{tabular}{|c|c|}
\hline R. v Howe \& Bannister [1987] AC 417 & $R v$ Gotts [1992] 2 AC 412 \\
\hline $\begin{array}{l}\text { As I can find no fair and certain } \\
\text { basis upon which to differentiate between } \\
\text { participants to a murder and as I am firmly } \\
\text { convinced that the law should not be } \\
\text { extended to the killer, I would depart from } \\
\text { the decision of this House in Director of } \\
\text { Public Prosecutions for Northern Ireland } v \text {. } \\
\text { Lynch [1975] A.C. } 653 \text { and declare the law } \\
\text { to be that duress is not available as a }\end{array}$ & $\begin{array}{l}\text { (...) As lord Griffiths pointed out } \\
\text { in the passage which I have just referred, } \\
\text { an intent to kill must be proved in the } \\
\text { case of attempted murder but not } \\
\text { necessarily in the case of a murder. Is } \\
\text { there logic in affording the defense to } \\
\text { one who intends to kill but fails and } \\
\text { denying it to the one who mistakenly } \\
\text { kills intending only to injure? }\end{array}$ \\
\hline
\end{tabular}




\begin{tabular}{|c|c|}
\hline $\begin{array}{l}\text { defense to a charge of murder, or to } \\
\text { attempted murder. I add attempted murder } \\
\text { because it is to be remembered that the } \\
\text { prosecution have to prove an even more } \\
\text { evil intent to convict of attempted murder } \\
\text { than in actual murder. Attempted murder } \\
\text { requires proof of an intent to kill, whereas } \\
\text { in murder it is sufficient to prove an intent } \\
\text { to cause really serious injury. It cannot be } \\
\text { right to allow the defense to one who may } \\
\text { be more intent upon taking a life than the } \\
\text { murderer. This leaves, of course, the } \\
\text { anomaly that duress is available for the } \\
\text { offence of wounding with intent but not to } \\
\text { murder if the victim dies subsequently. But } \\
\text { this flows from the special regard that the } \\
\text { law has for human life, it may not be } \\
\text { logical but it is real and has to be accepted. } \\
\text { (Lord Griffiths, our italics to underline the } \\
\text { ratio decidendi, the rest being obiter } \\
\text { dictum) }\end{array}$ & $\begin{array}{l}\text { It is of course true that } \\
\text { withholding the defense in any } \\
\text { circumstances will create some } \\
\text { abnormalities but I would agree with } \\
\text { Lord Griffiths that nothing should be } \\
\text { done to undermine in any way the } \\
\text { highest duty of the law to protect the } \\
\text { freedom and lives of those that live under } \\
\text { it. I can therefore see no justification in } \\
\text { logic, morality or law in affording to an } \\
\text { attempted murderer the defense which is } \\
\text { withheld from a murderer. (Lord Jauncey } \\
\text { of Tullichettle. Our italics to underline } \\
\text { the ratio decidendi, the rest being obiter } \\
\text { dictum). }\end{array}$ \\
\hline
\end{tabular}

Example 4: Illustration of how obiter dictum is re-used as ratio decidendi in a subsequent case

In American common law, the distinction between ratio decidendi and obiter dictum is less commonly used since American lawyers and judges use the expression "holding" to refer to the British ratio decidendi. Nevertheless, in any ruling handed down by US Supreme Court Justices, there is a part of the decision that will legally bind the lower courts in similar cases. To sum up, the ratio decidendi or holding is based, in both countries, on the same legal doctrine of stare decisis, i.e. "to keep to what has been decided before." Even if, at first sight, words or expressions may appear different, the principles and mechanisms at the core of American and English common law systems are widely similar. The rule of precedent is one of them. It first appeared in 1861 when the House of Lords stated that it felt it was bound by its own decisions, and is also applied in American common law. The question, therefore, is whether the rule of precedent is applied in the same way in American and British law.

Some legal scholars argue that the rule of precedent is more flexible in the American legal system than in the UK's. A quotation from Burnet v. Coronado Oil and Gas Co. (285 U.S. 393) by Justice Brandeis (dissenting) illustrates this flexibility:

Stare decisis is not, like the rule of res judicata, universal inexorable command. The rule of stare decisis is not inflexible. Whether it shall be followed or departed from, is a question entirely within the discretion of the court, which is again called upon to consider a question once decided (405-406). 
This affirmation emphasizes the flexible nature of precedent in American Common law. It is not uncommon for the US Supreme Court to overrule its previous decisions if they are no longer considered relevant, fair or justified. In 1992, in Planned Parenthood of Southeastern PA v. Casey 505 U.S. 833 (1992), Justice O'Connor wrote:

Because neither the factual underpinnings of Roe's central holding nor our understanding of it has changed (and because no other indication of weakened precedent has been shown), the Court could not pretend to be reexamining the prior law with any justification beyond a present doctrinal disposition to come out differently from the Court of 1973. To overrule prior law for no other reason than that would run counter to the view, repeated in our cases, that a decision to overrule should rest on some special reason over and above the belief that a prior case was wrongly decided (864).

Perhaps the most spectacular example of overruling precedents is the case Brown $v$. Board of Education of Topeka, mentioned earlier, in which the US Supreme Court struck down the legal principle of separate but equal that it had itself formerly established in Plessy v. Ferguson. The interpretation of the Constitution changed between the end of the $19^{\text {th }}$ century and the middle of the $20^{\text {th }}$ century, henceforth granting the court the right to depart from its own legal precedent:

Whatever may have been the extent of psychological knowledge at the time of Plessy $v$. Ferguson, this finding is amply supported by modern authority. Any language in Plessy $v$. Ferguson contrary to this finding is rejected (Justice Warren, 1954: 482-483).

Even though British law lords were bound by their own judgments until 1966, it seems that the rule of precedent has also been applied with some degree of adaptability in English common law. As a matter of fact, the notion of judge-made law is frequently presented as being adaptable to the current needs of society. Judges may create or adapt the law in accordance with the new societal context in which it is applicable. An example of the adaptability of judge-made law and the power of creation of judges may be seen in the Gillick case, in which Lord Denning refuses to consider precedents that originated in Victorian England but were still binding in 1985:

(...) I would get rid of the rule in Re Agar-Ellis and of the suggested exceptions to it. That case was decided in the year 1883. It reflects the attitude of a Victorian parent towards his children. He expected unquestioning obedience to his commands (...). The common law can, and should, keep pace with the times. It should declare, in conformity with the recent report of the Committee on the Age of Majority (Cmnd 3342) that the legal right of a parent to the custody of a child ends at the eighteenth birthday and even up till then, it is a dwindling right which the courts will hesitate to enforce against the wishes of the child, the older he is. It starts with a right of control and ends with little more than advice (Parker L.J., 1986: 129; our italics).

Hence, one might more readily refer to the British common law as being adaptable, in comparison to American common law which could more appropriately be 
characterised as flexible. In spite of this minor difference, the rule of precedent gives a good example of one aspect of common law which is common to both the US and the UK.

With regard to dissenting opinions, one may wonder why they are integrated into American and British judicial decisions when only the majority opinion of the US Supreme Court or the judgment of the UK Supreme Court is legally binding.

In American common law, every case is more or less based on a reading of the US Constitution construed through either a narrow or a wide interpretation. The former provides that if the constitution does not say something can be done, then it cannot be done, while the latter says that if the constitution does not say something cannot be done, then it can be done. Based on the plurality of possible constitutional interpretations, American common law allows judges to share their points of view on the case, including in dissenting opinions. As a result, the final text is polyphonic, like a piece of music in which different voices are heard which sometimes harmonize while at other times they are dissonant. It is thus important to be able to detect the linguistic signs underlying the polyphony in US Supreme Court decisions. The 'flashback' structure illustrates this polyphony with expressions such as ante used to refer to what has been said previously in another part of the decision, sometimes in the opinion of the Court. In Deborah Morse, et al., Petitioners v. Joseph Frederick, a case related to the First Amendment and the constitutionality of the measures implemented by public schools to prohibit students from displaying messages promoting the use of illegal drugs at school-supervised events, one judge, Justice Stevens dissented and wrote:

I would hold, however, that the school's interest in protecting its students from exposure to speech reasonably regarded as promoting illegal drug use, ante, at 1 , cannot justify disciplining Frederick for his attempt to make an ambiguous statement to a television audience simply because it contained an oblique reference to drugs (Stevens, dissenting, 2007: 1).

Furthermore, the most significant interest of dissenting opinions from the legal point of view is their persuasive force, i.e. the fact they constitute incentives for lower court judges. In subsequent cases dealing with similar issues, they can reinforce a judge's argument when s/he may want to overrule a precedent and require arguments and justifications to do so. In the UK, judges, and especially justices of superior courts, are highly respected. The foundation of this respect is perhaps as social as it is legal. British legal professionals benefit from it all the more so as senior judges are former barristers who generally receive a knighthood. As such, a minority opinion written by a British senior judge, even though it may have no legal enforceability on the case stated, is nonetheless considered as valuable and worth being brought to the attention of practising lawyers. Moreover, the value of the dissenting opinion may appear relevant later, for example in appeal, when the superior court supports the position of the dissenting judge in the lower court or when the dissenting opinion presented at any given time becomes the one on which case law is overturned later on. 
Finally, dissenting opinions can be read retrospectively as an anticipation of what may later occur as can be seen in Justice Black's dissenting opinion in the US case of Tinker v. Des Moines Independent Community School District 393 U.S. 503, which related to the constitutionality of a prohibition against the wearing of armbands in public school as a form of symbolic protest:

One does not need to be a prophet or the son of a prophet to know that, after the Court's holding today, some students in Iowa schools -- and, indeed, in all schools -- will be ready, able, and willing to defy their teachers on practically all orders. [...] I wish, therefore, wholly to disclaim any purpose on my part to hold that the Federal Constitution compels the teachers, parents, and elected school officials to surrender control of the American public school system to public school students. I dissent (Black, dissenting, 1969: 525-526).

Some years later, in Deborah Morse, et al., Petitioners v. Joseph Frederick, Justice Thomas wrote in his concurring opinion:

Justice Black may not have been "a prophet or the son of a prophet," but his dissent in Tinker has proved prophetic 393 U. S. at 525. [...] We need look no further than this case for an example: Frederick asserts a constitutional right to utter at a school event what is either "[g]ibberish," ante, at 7, or an open call to use illegal drugs. To elevate such impertinence to the status of constitutional protection would be farcical and would indeed be to "surrender control of the American public school system to public school students." Tinker, supra, at 526 (Thomas, 2007: 12-13).

In American and British common law alike, dissenting opinions can thus be seen to play a vital role in a legal system based on case law and as such are fully integrated in the ruling. The final text of the decision is shaped by British and American judges according to their own reasoning methods. However, do judges from both countries have the same legal reasoning techniques? Do these mechanisms have an impact on the language used in superior court decisions?

\section{Language and legal reasoning mechanisms}

In the UK, when a point of law is raised, judges have to give a decision regarding the points of law and, when necessary, an interpretation of statutory provisions. This interpretation will become as binding as the statutory provisions themselves. As pointed out by David (1972: 81), "English statutes truly become English law after they have been enshrined in judicial decisions". ${ }^{18}$ However, in British common law the judge's power of interpretation is narrowly circumscribed by reading techniques: words must be construed literally sticking to their plain sense, either legal or ordinary depending upon the context. However where no text defines the issue, judges will create new legal terms and principles.

The legal techniques of interpretation are organized according to a hierarchy of rules that significantly limit the power of judges. The literal rule of interpretation, also known 
as "the plain meaning rule" - not to be confused with Plain English- prevails in any situation where the terms of the statute are clear enough, even if the result is considered unsatisfactory. However, when the terms of the Act are not clear, the second rule of statutory interpretation, called the "golden rule", can be used. According to this rule, judges can depart from the literal rule so as to avoid any absurdity in the result of the interpreting process. As expounded by Lord Esher in $R v$ Judge of the City of London Court [1892] 1 Q.B. 273:

\begin{abstract}
“(...) If the words of an Act are clear, you must follow them, even though they lead to a manifest absurdity. The Court has nothing to do with the question whether the legislature has committed an absurdity." [literal rule] "In my opinion, the rule has always been this - if the words of an Act admit of two interpretations, then they are not clear; and if one interpretation leads to an absurdity, and the other does not, the Court will conclude that the legislature did not intend to lead to an absurdity, and will adopt the other interpretation." [golden rule] (290, hook brackets added to highlight the use of the literal rule and the golden rule).
\end{abstract}

Where the first two rules of interpretation cannot solve the difficulty, judges resort to the third called "the mischief" or "defect rule": they scrutinize Parliament's original purpose and intention when the Act was passed in order to come to an appropriate interpretation of the Act. One famous illustration of this technique can be found in a criminal case relating to six prostitutes who challenged their charges of solicitation under the Street Offences Act 1959, arguing that they were soliciting in private premises from behind their windows or from their balconies. In Smith v Hughes [1960] 1 WLR 830, Lord Parker provides an illustration of the mischief rule:

(...) Everybody knows that this was an Act to clean up the streets, to enable people to walk along the streets without being molested or solicited by common prostitutes. Viewed in this way it can matter little whether the prostitute is soliciting while in the street or is standing in the doorway or on a balcony, or at a window, or whether the window is shut or open or half open (832).

Lastly, it is worth mentioning that the particular technique of teleological analysis has been more recently used by British judges. This technique, which refers to the spirit of the text, is hardly ever applied for interpreting British statutes which usually tend to be very detailed and accurate. Nevertheless, it sometimes helps British judges to interpret European Union Regulations that are mostly written in typically civilian style, with which British judges are neither familiar nor at ease.

In American common law, the question of the interpretation of a (federal or state) law is settled through a reading of the US Constitution. Every case decided by the US Supreme Court boils down to a constitutional question. Justices have to decide if the statutory provisions of the piece of legislation being challenged are in keeping with the supreme law of the land. Justice Frankfurter once said in his concurring opinion in Graves v. New York 306 U.S. 466, that "the ultimate touchstone of constitutionality is 
the Constitution itself and not what we have said about it" (491-492). Oliver Wendell Holmes, as early as 1899, stated that "We do not ask what the lawmaker could have meant; we do not try to know what the Act means". ${ }^{19}$ An American judge does not consider himself a collaborator of the lawmaker (Levasseur, 2004: 118). His role is not to find the intention of the legislative body behind the text. This is the reason why the main method of legal interpretation in the American common law system is the plain meaning rule, and only if the textual interpretation leads to absurd and unfair solutions will the intention of the lawmaker be analysed.

Finally, when no legal provision regulates the issue at stake, common law judges have the power to create new legal principles that will subsequently rule the issue and bind lower courts. One of the best examples of British judge-made law and its subsequent terminological creations is the well-known "neighbour principle". The principle was created by Lord Atkin in Donoghue v Stevenson [1932] UKHL 100, also known as the "Snail in the Bottle case", according to which reasonable care must be taken to avoid acts or omissions likely to injure "a neighbour". The legal principles ruling liability for negligence were based on this case, giving rise to new developments of tort law. This mechanism has subsequently been referred to as the "neighbour principle":

You must take reasonable care to avoid acts or omissions which you can reasonably foresee would be likely to injure your neighbour. Who then in law is my neighbour? The answer seems to be persons who are so closely and directly affected by my acts that I ought reasonably to have them in contemplation as being so affected when I am directing my minds to the acts or omissions which are called in question (Lord Atkin, 580).

All the legal criteria on which negligence is based are present in this paragraph: negligence can be established when the tortfeasor is in a position where $\mathrm{s} / \mathrm{he}$ could foresee the damage caused by his/her act to the victim and has failed to prevent it from happening.

Similarly, US Supreme Court Justices have the power to interpret the text of the US Constitution so as to establish rights that have not explicitly been expressed in the supreme law of the land. This was the case in landmark case Roe v. Wade 410 U.S. 113 (1973) on abortion:

The Constitution does not explicitly mention any right of privacy. In a line of decisions, however, going back perhaps as far as Union Pacific R. Co. v. Botsford, 141 U.S. 250, 251 (1891), the Court has recognized that a right of personal privacy, or a guarantee of certain areas or zones of privacy, does exist under the Constitution. [...] This right of privacy, whether it be founded in the Fourteenth Amendment's concept of personal liberty and restrictions upon state action, as we feel it is, or, as the District Court determined, in the Ninth Amendment's reservation of rights to the people, is broad enough to encompass a woman's decision whether or not to terminate her pregnancy (Justice Blackmun, 1973: 152$153)$. 
This quotation illustrates the power of US Supreme Court Justices to create and develop new legal principles through a wide interpretation of constitutional provisions. This is the American version of judge-made law applied pursuant to the doctrine established in 1819 in McCullogh v. Maryland 100 U.S. 421:

Let the end be legitimate, let it be within the scope of the Constitution, and all means which are appropriate, which are plainly adapted to that end, which are not prohibited, but consistent with the letter and spirit of the Constitution, are constitutional (421).

Additionally, the power of creation of common law judges, British and American alike, sometimes goes beyond the establishment of a legal principle, giving rise to practical legal tools for practitioners. When ruling on a case, judges have the possibility to set principles and define tools that may be taken up in future legal situations. In the Gillick case already mentioned, in obiter dictum Lord Fraser introduced a comprehensive test that helped medical practitioners assess whether they would be failing to discharge their professional responsibilities by providing contraceptive advice to a minor without parental consent:

(...) But there may well be cases, and I think there will be some cases, where the girl refuses either to tell the parents herself or to permit the doctor to do so and in such cases the doctor will, in my opinion, be justified in proceeding without the parents' consent or even knowledge provided he is satisfied on the following matters: (1) that the girl (although under 16 years of age) will understand his advice (2) that he cannot persuade her to inform her parents or to allow him to inform the parents that she is seeking contraceptive advice (3) that she is very likely to begin or to continue having sexual intercourse with or without contraceptive treatment (4) that unless she receives contraceptive advice or treatment her physical or mental health or both are likely to suffer (5) that her best interests require him to give her contraceptive advice, treatment or both without the parental consent (our italics, 1986: 174).

Lord Fraser based this test on five criteria that must be assessed by any medical practitioner before making the decision to prescribe such a treatment or procedure to girls who are underage. Though this test was created with "contraceptive treatments" in mind (to quote Lord Fraser himself), it was later considered to be sufficiently clear and useful to be used in any situation when a minor seeks medical advice or treatment without informing his/her parents. Since that date, this test has been known as the "Gillick competence test" for academics and practitioners, and has been adapted to other cases when a practitioner needs to assess the maturity of the child.

Similarly, in the 1966 American criminal case Miranda v. Arizona 384 U.S. 436 which gave rise to the famous "Miranda Rights", US Supreme Court Justices established legal and professional guidelines for law enforcement to respect when a suspect is arrested and taken into police custody:

As for the procedural safeguards to be employed, unless other fully effective means are devised to inform accused persons of their right of silence and to assure a continuous 
opportunity to exercise it, the following measures are required. Prior to any questioning, the person must be warned that he has a right to remain silent, that any statement he does make may be used as evidence against him, and that he has a right to the presence of an attorney, either retained or appointed (our italics, 444).

These two cases, one British, the other American, underscore the power of common law judges to set out principles and legal tools for professionals both in the UK and the US.

\section{Conclusion}

This paper has highlighted the existence of some common features in the American and English common law systems such as a largely common language, as well as similar concepts, principles and procedures. English common law undoubtedly remains the original and founding source of American law. The comparison between American and British decisions handed down by US and UK superior courts, through a legal and linguistic analysis, has highlighted these convergences. The rule of precedent is similarly implemented in both legal systems in spite of minor structural differences pointed out in the judicial decisions that have been studied.

Nevertheless, there are differences which indicate quite clearly that the American and the English common law systems not so common after all. The legal terminology is both similar and different, as illustrated by the term 'judicial review' present in both systems but which does not refer to the same legal reality. Moreover, while English and American judges are both empowered to create new legal concepts, the way in which texts are interpreted (and court decisions drafted) are distinct. In addition, the flexibility used by American judges is not strictly comparable to the adaptability that characterises English common law - leading us to conclude that, with regard to the cross-cultural aspects of even close-culture disciplines, a constant look-out for "false" or "true" friends is an undisputable prerequisite.

\section{Notes}

1. 47 States are pure common law systems, without counting the bi-juridical ones. See <www.juriglobe.ca/fra/sys-juri/class-poli/common-law.php>, consulted on 23 July 2015.

2. See Waghorn v Waghorn, 297: Dixon, J., in an Australian case: "Where a general proposition is involved the court should be careful to avoid introducing in Australia a principle inconsistent with that accepted in England. The common law is administered in many jurisdictions and unless each guards against needless divergencies of decision its uniform development is imperilled".

3. See Zoller (2014): 5, consulted on 23 July 2015.

4. For more information on the US Supreme Court, see the US Supreme Court website: $<$ http://www.supremecourt.gov/>, consulted on 23 September 2015. 
5. Interestingly, the American term used to refer to the application before the US Supreme Court, "to file for a writ of certiorari", comes from English common law which abolished this terminology in 1938. The UK has replaced it with the more transparent expression "application for permission to appeal".

6. See <https://www.supremecourt.uk/about/uk-judicial-system.html>.

7. Section 124(2) Criminal Procedure (Scotland) Act 1995.

8. On these particularities, see the UK Supreme Court website: $<$ https://www.supremecourt.uk/docs/jurisdiction-of-the-supreme-court-in-scottishappeals.pdf>, consulted on 27 July 2015.

9. The following Acts are of constitutional nature with regard to continental standards: Magna Carta 1215, Habeas Corpus Act 1679, Bill of Rights 1689, Act of Union 1707, Act of Union 1801, Human Rights Act 1998.

10. On the power of the UK Supreme Court with respect to constitutional protections, see Olivier Deparis (July 2011). "La Cour suprême au Royaume-Uni et la question de constitutionnalité", Nouveaux Cahiers du Conseil constitutionnel $\mathrm{n}^{\circ} 32$ (Dossier: RoyaumeUni). Available online at <http://www.conseil-constitutionnel/francais/nouveaux-cahiers-duconseil/cahier-n-32/la-cour-supreme-au-royaume-uni-et-la-question-de-constitutionalite-parolivier-deparis.99061.html>, consulted on 27 July 2015.

11. For the definition of judicial review, see the website of federal courts in the USA: $<$ http://www.uscourts.gov/>, consulted on 23 September 2015.

12. The British and Irish Legal Information Institute (BAILII) website publishes British and Irish case law and legislation, European Union case law, Law Commission reports, and other law-related British and Irish material.

13. In the American context, the word 'judgment' refers to the outcome of the case as opposed to the holding, i.e. the legal reasons and arguments presented to justify the judgment. In the UK, a judgment is used to refer both to the outcome and the legal reasoning from which it ensues.

14. E.g. in the famous Gillick case, Lord Fraser is clearly organizing his reasoning considering the grounds for appeal with digits from 1 to 6. See Gillick $v$ West Norfolk \& Wisbeck Area Health Authority [1986] AC 112, Lord Fraser of Tullybelton's opinion.

15. A. L. Goodhart: "Determining the ratio decidendi of a case" (1930) 40 Yale LJ 161 and Goodhart: "The ratio decidendi of a case" (1959) 22MLR 117.

16. Cf Balfour v Balfour [1919] 2 KB 571 and Merritt v Merritt [1970] 1 WLR 1211. In these two cases the enforcement of a maintenance agreement passed between spouses that were not living together was claimed. However, the position of Balfour was not considered as binding on the Merritt case because the context of the agreement was different. In the Balfour case, the spouses were living apart because of some health problem that prevented the wife to follow her husband abroad. In the Merritt case the spouses were living apart because they were about to get divorced. The lack of contractual intention presumption in agreement passed by spouses that was held in Balfour was not extended to an agreement passed by a couple who was about to divorce such as the one in the Merritt case.

17. On this issue, see Hans-Albreicht Schwarz-Lieberman von Wahlendorf (1999), "Le juge 'législateur' l'approche anglaise". RIDC 4: 1109-1117.

18. See David, H. (1972). Introduction à l'étude du droit écossais. Paris: LGDJ: 81. "la loi anglaise n'est véritablement incorporée au droit anglais que lorsqu'elle a reçu la consécration de la jurisprudence". Quotation translated into English by L. Francoz Terminal. 
19. Holmes, Oliver Wendell (1899). "The Theory of Interpretation". Harvard Law Review 12: 417-420. Quoted in S\&E Contractors, INC. v. United States 406 U.S. 1 (1971).

\section{References}

\section{Primary sources}

American cases

Berghuis v. Thompkins 560 U.S. (2010)

Black and White Taxicab \& Transfer Co. v. Brown \& Yellow Taxicab \& Transfer Co. 276 U.S. 518 (1928)

Brown v. Board of Education of Topeka 347 U.S. 483 (1954)

Burnet v. Coronado Oil and Gas Co. 285 U.U. 393 (1932)

Deborah Morse, et al., Petitioners v. Joseph Frederick 551 U. S. (2007)

Ernst \& Ernst v. Hochfelder 425 U.S. 185 (1976).

Glossip v. Gross 576 U.S. _ (2015)

Graves v. New York 306 U.S. 466 (1939)

Lawrence v. Texas 539 U.S. 558 (2003)

Marbury v. Madison (1803) 5 U.S. 137 (1803)

McCullogh v. Maryland 100 U.S. 421 (1819)

Miranda v. Arizona 384 U.S. 436 (1966)

Plessy v. Ferguson 163 U.S. 537 (1896)

Roe v. Wade 410 U.S. 113 (1973)

Schuette, Attorney General of Michigan v. Coalition to defend Affirmative Action, Integration and Immigration Rights and Fight for Equality by any Means Necessary (BAMN) et al. 572 U.S. (2014)

Tinker v. Des Moines Independent Community School District 393 U.S. 503 (1969)

United States v. Detroit Timber \& Lumber Co, 200 U.S. 321 (1906)

British cases

All British cases can be consulted at the website of the British and Irish Legal Information Institute URL <http://www.bailii.org/>.

Gillick v West Norfolk \& Wisbeck Area Health Authority [1986] AC 112

Murray v DPP [1994] 1 WLR 1

$R v$ Gotts [1992] 2 AC 412

$R v$ Howe \& Bannister [1987] AC 417

$R v$ Judge of the City of London Court [1892] 1 Q.B. 273

Quinn v Leathem [1901] AC 495

Smith v Hughes [1960] 1 WLR 830

Sue Axon v The Secretary State of Health [2006] EWHC 37 (Admin)

Waghorn v Waghorn [1941-1942] 65 C.L.R. 289 


\section{Secondary sources}

Blackstone, William (1893): Commentaries on the Laws of England in Four Books. Philadelphia: J.B. Lippincott Co. <http://oll.libertyfund.org/title/2140>.

Bullier, Antoine J. (2012): La common law. Paris: Dalloz.

David, Hélène (1972): Introduction à l'étude du droit écossais. Paris: LGDJ.

Gibson-Morgan, Elizabeth (2014). "The United Kingdom Supreme Court and Devolution Issues: Towards Constitutional Review?" Miroirs 1: 84-111, < http://www.revuemiroirs.fr/links/Article8.pdf>.

Goodhart, Arthur L. (1930): "Determining the ratio decidendi of a case". Yale Law Journal 40(2): 161-183.

. (1959): "The ratio decidendi of a case". Modern Law Review 22(2): 117-124.

Holmes, Wendell (1899): "The Theory of Interpretation". Harvard Law Review 12: 417-420.

Levasseur, Alain (2004): Le droit américain. Paris: Dalloz.

Regan, Richard J. (2015). A Constitutional History of the U.S. Supreme Court. Washington D.C.: The Catholic University of America Press.

Schwarz Libermann von Wahlendorf, Hans-Albreicht (1999): "Le juge législateur, l'approche anglaise". Revue internationale de droit comparé, 51(4): 1109-1117.

Zoller, E. (2014). Le droit des États-Unis. Available online. <http://www.uparis2.fr/servlet/com.univ.collaboratif.utils.LectureFichiergw?ID_FICHE=45022\&OBJET= 0015\&ID_FICHIER=877682>. 